\title{
MATERIAL LOOPS POTENTIAL IN POST-DISASTER TRANSITIONAL SHELTER: LEARNING FROM 2010 MERAPI ERUPTION
}

\author{
Widyarko*, Khalda Fadhilah Arisya*, Nisrina Dewi Salsabila*, Linda Firlie \\ Pratiwi* \\ *) Department of Architecture, Universitas Indonesia \\ e-mail: widyarko01@ui.ac.id
}

\begin{abstract}
Due to the geographic condition of the country, Indonesia is very vulnerable to natural disasters (BNPB, 2017). As a response, this country has various mechanisms of assistance to disaster-affected communities and assistance to fulfil basic needs for disaster victims, one of which includes the provision of 'huntara' as temporary shelter for the victims (BNPB, 2008). Because of its temporary nature, transitional shelters in Indonesia generally have a relatively short life cycle of building materials and may produce quite the amount of waste which would be harmful to the environment. This study attempts to understand the material life cycle process in transitional shelters built during the eruption of Mount Merapi Eruption in 2010. This study uses the approach of qualitative research with two main data collection methodsobservations and interviews. This study found that the design of transitional shelter for this disaster had allowed for most of the building components to principles of Design for Disassembly, which supports the potential for material loops to occur and possibly to fulfil the characteristics of sustainable transitional shelter. However, neither the victims nor the aid providers were fully aware of this potential: thus, it could not be optimally utilised. This condition is quite unfortunate, considering that Indonesia is very prone to disasters so that transitional shelters will often be needed. Therefore, further studies are required to formulate various design standards for transitional shelter in Indonesia to optimise the potential for longevity and minimise environmental impacts.
\end{abstract}

Keywords: huntara, transitional shelter, disaster, material loop, design for disassembly

\section{INTRODUCTION}

A disaster is an event or series of events that threatens and disrupts people's lives and livelihoods, caused by natural factors and/or non-natural factors as well as human 
factors, resulting in human casualties, environmental damage, property losses, and psychological impacts (RI Law No. 24/2007 Article 1). The geographic condition of Indonesia - an archipelago country, located at the junction of four tectonic plates, and surrounded by volcanic belts on the eastern and southern sides-makes it very vulnerable to various disasters, especially natural disasters (BNPB, 2017). This issue is confirmed by the results of records carried out by the National Disaster Management Agency (BNPB) which states that the number of natural disasters that occurred in Indonesia from 2011 to 2020 was recorded at more than 30,000 incidents (BNPB, 2020).

Considering that Indonesia is a country that is no stranger to disasters, there are various mechanisms of assistance to disaster-affected communities and assistance to fulfil basic needs for disaster victims in Indonesia. One form of fulfilment of basic requirements provided by the government is a temporary shelter (huntara) for the disaster victims in the refuge (BNPB, 2008). Because it is expected that they are only temporary and need to be erected immediately, temporary shelters generally have unique characteristics such as light materials and easy construction, so they do not cost a lot of money (Juanda, 2020 in Putra, 2020). When a more permanent housing has been built, these temporary shelters are often dismantled immediately, causing a relatively short life cycle of building materials. In fact, the material life cycle is one of the main issues that is often raised in discussions about the green building concept: a green building needs to incorporate the idea of a closed-loop material cycle. According to Kibert (2013), closed-loop cycle occurs where building materials and elements can be repurposed into buildings through certain processes. Unfortunately, the idea of applying the closed-loop material cycle tends only to target permanent structures, while buildings that are short-lived and temporary such as temporary shelters often go unnoticed.

The ubiquitous disasters in Indonesia, of course, end with the construction of massive temporary shelters with a brief life span. For example, to respond to the eruption of Mount Merapi in 2010, more than 2000 housing units needed to be built (Latief, 2011). Yet, only three years later, the dwelling had to be demolished so that the land could be reused (Setiyoko and Mardiani, 2013). This demolition process could also result in the increase of waste, especially from used materials. Because at this time the environmental problem is one of an urgent issue: thus, the implementation of the transitional shelter design in Indonesia also needs to be studied further, so that in the future it can minimise waste from the post-use. For this reason, efforts were made to understand how the material life cycle process in transitional shelters built during one of the disasters in Indonesia, namely the eruption of Mount Merapi in 2010.

This paper consists of five sections: introduction, theoretical review, methodology, results and discussion, and conclusion. The introduction section elaborates the background and objectives of this study. Theoretical review consists of two sub-sections: the first one discusses huntara as post-disaster transitional shelter in Indonesia, whereas the second one discusses post-disaster transitional shelter from the point of view of sustainable construction. Methodology elaborates on the methods taken by the authors to conduct this research, including literature review, data collections, and data analysis. As for results and discussion, this section consists of 
two sub-sections: the first one discusses the overview of data collection regarding the 2010 Mount Merapi Transitional Shelter, whereas the second one discusses the data analysis. Finally, the conclusion summarizes the author's findings, as well as incorporating suggestions for future studies or implementation.

\section{THEORY / RESEARCH METHODS}

\section{Huntara as Post-Disaster Transitional Shelter in Indonesia}

The provision of post-disaster shelter for disaster victims is vital for their survival (Jha, 2010; Kronenburg, 2014). In Indonesia, the procurement of post-disaster shelter is regulated in the law as one of the basic human needs that must be met in an emergency response condition (RI Law No. 24/2007 Article 48; RI Law No. 24/2007 Article 53).

In general, post-disaster shelter includes several stages: starting from an emergency shelter which needs to be provided soon after the disaster occurs, the form can be in the form of refugee barracks, emergency tents, or can use public buildings such as schools or stadiums (IFRC, 2010; Zhao et al., 2017); to a durable/permanent housing for the victim as a substitute for their old residence (Jha, 2010). However, in its implementation, a 'middle' phase is often required when the emergency phase has passed so that the emergency shelter is no longer suitable, whereas durable/permanent housing are not yet completed (UNDRO, 1982; IFRC, 2011; IFRC and UN-OCHA, 2015). The shelters used in this phase is known as a transitional shelter, which will be used as a place of refuge for disaster victims that are between an emergency phase until they can build a more long-term residence (IFRC, 2011; DFID, 2012).

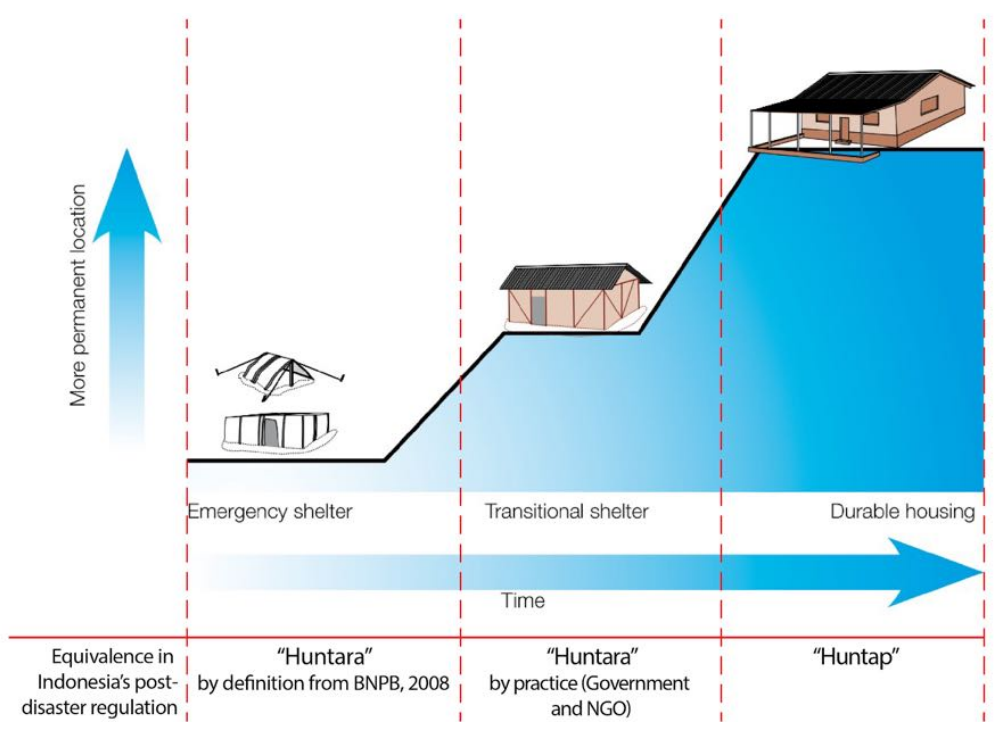

Figure 1. Shelter stages in disaster management source: International Federation of Red Cross and Red Crescent Societies, 2011 (reproduced) 
In Indonesia, that there are two known forms of shelters provided as a form of disaster management, namely: (1) hunian sementara (huntara) as temporary shelters during the displacement of disaster victims, either in the form of mass shelters up to the more private shelters for families or individuals (BNPB, 2008); and (2) hunian tetap (huntap) in the form of a more permanent residence for disaster victims. Huntara assistance is provided in the form of tents, barracks, or temporary public/social facility buildings that can be used as temporary housing (BNPB, 2008). Whereas in practice, assistance with the term 'huntara' is often provided in the form of building a shelter with a structure and construction that is stronger than a tent. Thus, it is understood that the term 'huntara' in Indonesia covers from emergency shelters to transitional shelters, while 'huntap' is equivalent to durable/permanent housing (figure 1).

\section{Post-Disaster Transitional Shelter and Sustainable Construction}

In general, the transitional shelter includes several requirements, including the ability to accommodate the affected family in a proper, closed and safe manner, have a healthy and safe living environment, and can maintain individual privacy and dignity (IFRC, 2010; Jha, 2010). If designed appropriately, transitional shelters can accommodate needs according to local culture, vulnerability and capacities of affected communities, and utilise available resources (Jha, 2010; IFRC, 2011). Furthermore, transitional shelters should be part of a continuous protection process: if appropriately designed, the material on the transitional shelters can be reused for the construction of a more permanent shelter (IFRC, 2011). This argument is also supported by the opinion of Kronenburg (2014) which states that emergency accommodation that is well designed and of adequate quality, in the end often continues to be part of the permanent housing occupied by victims. For this reason, aspects such as relocation, reconstruction, and recycling or reuse of material from a transitional shelter are something that should be considered (Jha, 2010; IFRC, 2011; DFID, 2012; Kronenburg, 2014).

In Indonesia, the criteria and standardisation of transitional shelter design related to the fate of this building after being demolished have not been widely discussed or determined. This fact is unfortunate considering that transitional shelters are quite crucial in disaster management as a form of support for the community before they can rebuild permanent residences (UNDRO, 1982; Jha, 2010; IFRC, 2011; Kronenburg, 2014).

In most countries, many rating agencies have reviewed the 'green' rating for a building: however, these rating agencies generally have different standards to solve the conditions and needs that exist in each country. The 'Material Loop' aspect is one of the points that is one of the fundamental elements of the assessment points that need attention as it is related to the idea of reusing materials to minimise waste while reducing the number of building embodied energy (Kibert, 2016). The main point in this aspect is not only discussing the source or use of materials in buildings, but also the future of these materials as they go through the post-demolition period to achieve a sustainable life cycle. One idea that also talks about the effectiveness of reuse and the future of materials is the principle of Design for Disassembly. Design for 
Disassembly or DfD is a design approach that is oriented to how the disassembly process will occur in a building. The word "disassembly" in the context of DfD refers to "systematic disassembly", namely how the order in which the disassembly process will be carried out is a reverse of the order in which the assembly process is applied (Cairns and Jacobs, 2014).

Crowther (1998) argues that designing a building for disassembly is a strategy for moving reuse and recycle, which results in improving sustainability. This argument is in line with the opinion of Jensen and Sommer (2016) which states that the purpose of DfD is not only related to construction speed but also to reduce waste by optimising upcycling, recycling, and reuse of material. By facilitating the reuse, recycling, and remanufacturing processes of building components, the application of DfD may reduce the embodied energy used in the assembly and disassembly processes (Crowther, 1999).

In DfD, to support both recycle and upcycle so that it can occur adequately, readability of material relations in the assembly system is essential (Cairns and Jacobs, 2014). This theory is also supported by a study conducted by Pramishinta and Widyarko (2021) which suggests that structural systems and construction methodsregarding how each material connects to one another to form a whole building-plays a role in determining the flexibility of a building. Crowther (1998) explains that there are several principles in the application of design for disassembly, which includes: (1) the use of lightweight materials, (2) separation layer between structural components and building envelopes, (3) the use of non-chemical and low-tech joints, and (4) the use of standard/modular components. With the separation between service and structure, each component will be more accessible or accessible without having to disturb or damage other parts (Guy and Shell, 2002).

The importance of layer separation is also discussed by Brand (1994), arguing that every layer in a building has different lifespan so it needs to be separated. In addition, this needs to be supported by avoiding the use of chemical connections such as concrete pouring and welding as well as the use of nails to prevent contamination and damage to the material when separated (Crowther, 1998; Guy and Shell, 2002). In comparison, the use of standard components can support the construction phase to be faster while supporting modification when rebuilt (reassembly) at a different location (Crowther, 1998). 


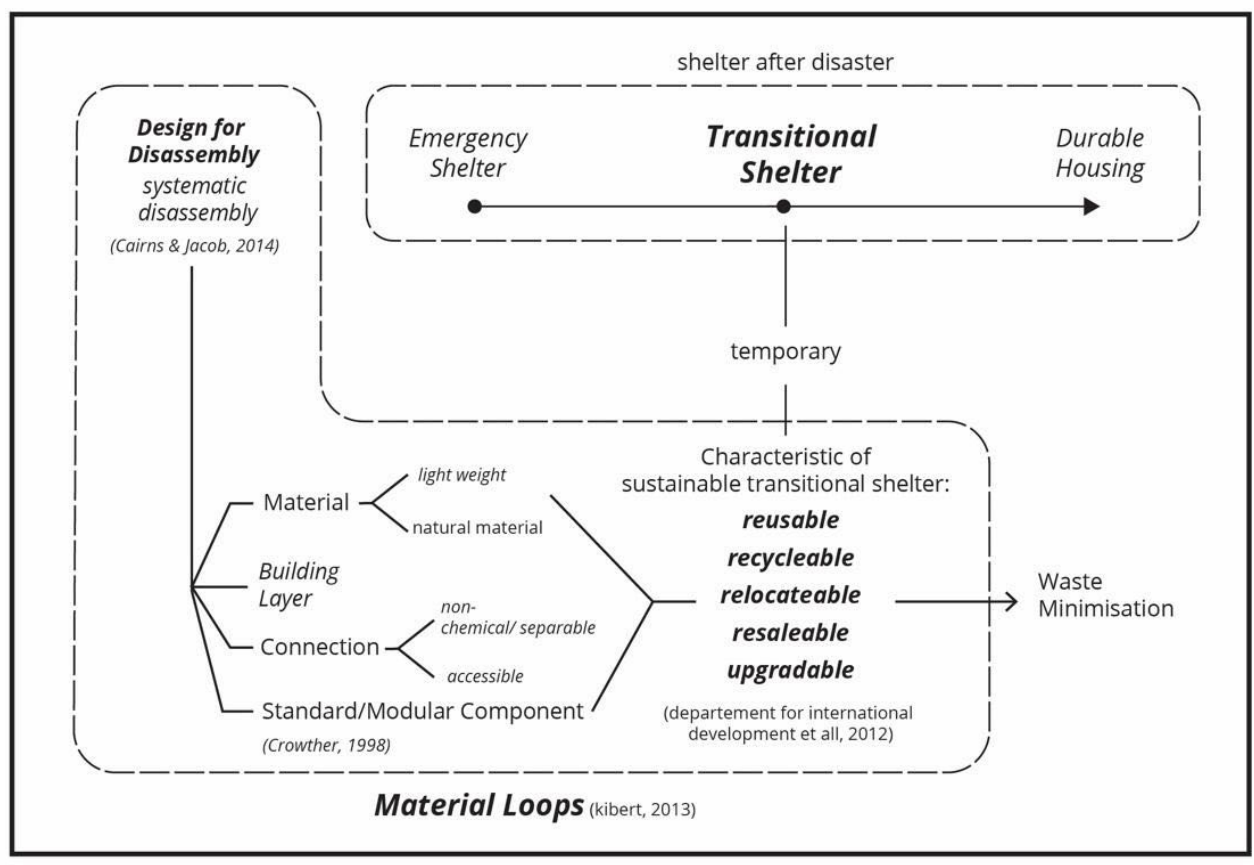

Figure 2. Material Loops Potential in Post-Disaster Transitional Shelter source: authors, 2020

The idea from DfD concerning the Material Loops aspect is relevant to the existence of a transitional shelter which must be built in a fast time and has a concise life so that an effort is needed to minimise the waste generated from the use of transitional shelters in order to have a sustainable cycle. According to DFID (2012), for the transitional shelter to have a life cycle or sustainable material, the transitional shelter needs to use five post-use characteristics. The five characteristics consist of upgradable, reusable, relocatable, resaleable, and recyclable.

- Upgradable relates to the ability for the transitional shelters to be repaired and added to become a solution to permanent housing over time.

- Reusable means that when the rehab-reconstruction period is over, and the affected community has switched to a durable housing, the transitional shelter can be converted into another place such as a warehouse, shop or other destination. In the context of DfD, this term not only refers to the reuse of building function, but also of building components and material to be reused in another building (Crowther, 1998).

- Relocatable means that when no longer in use, the transitional shelter can easily be moved to a permanent location or moved to be reused at another disaster.

- Resaleable means that after the affected community has switched to durable housing, the transitional shelter can be dismantled, and the material can be resold.

- Recyclable means the process of reconstructing a durable housing, the transitional shelter can be dismantled in stages, and the demolished material can be used in the reconstruction process. 
These characteristics are also in line with the objectives of DfD, as previously described (Crowther, 2001). Thus, it is understood that the DfD principles can act as a benchmark for reviewing the potential for Material Loops on the design of transitional shelters in Indonesia, including the one used in the Mount Merapi disaster (figure 2; table 1).

Table 1. Principles of DfD in supporting the design of sustainable transitional shelter

\begin{tabular}{|c|c|c|c|c|c|c|}
\hline \multirow{2}{*}{$\begin{array}{l}\text { Principles of } \\
\text { DfD }\end{array}$} & \multicolumn{5}{|c|}{ Characteristic of Sustainable Transitional Shelter } & \multirow{2}{*}{ Reference } \\
\hline & Upgradable & Reusable & Recyclable & Relocatable & Resalable & \\
\hline \multicolumn{7}{|l|}{ Materials } \\
\hline $\begin{array}{l}\text { Natural } \\
\text { Material }\end{array}$ & - & - & $\begin{array}{l}\text { Eliminate } \\
\text { toxicity or } \\
\text { future use } \\
\text { and } \\
\text { disposition. }\end{array}$ & - & - & {$[1]$} \\
\hline Lightweight & - & - & - & $\begin{array}{l}\text { Easily } \\
\text { disassembled } \\
\text { \& transported } \\
\text { to a new site. }\end{array}$ & - & {$[2]$} \\
\hline $\begin{array}{l}\text { Separated } \\
\text { Layer }\end{array}$ & \multicolumn{5}{|c|}{$\begin{array}{l}\text { Easily disassembled to make } \\
\text { modifications, accommodate changes \& maintenance without } \\
\text { disturbing another layer. }\end{array}$} & {$[2]$} \\
\hline \multicolumn{7}{|l|}{$\begin{array}{l}\text { Joint and } \\
\text { Construction }\end{array}$} \\
\hline Separable & \multicolumn{5}{|c|}{$\begin{array}{l}\text { Allow the building component to be disconnected, prevent } \\
\text { materials degradation. }\end{array}$} & {$[3]$} \\
\hline Accessible & \multicolumn{5}{|c|}{ Provide access to all parts and connection points } & {$[2]$} \\
\hline $\begin{array}{l}\text { Standard } \\
\text { Component }\end{array}$ & - & $\begin{array}{l}\text { Allowed } \\
\text { interchange- } \\
\text { ability. }\end{array}$ & - & $\begin{array}{l}\text { Allowed for } \\
\text { fast \& } \\
\text { efficient } \\
\text { construction } \\
\text { sequences. }\end{array}$ & - & {$[2]$} \\
\hline
\end{tabular}

References: [1] Guy and Shell, 2002; [2] Crowther, 1998; [3] Cairns and Jacobs, 2014

This study discusses transitional shelters during the eruption of Mount Merapi in 2010. The method used is qualitative research involving interpretive and naturalistic approaches to the subject matter. Naturalistic approach means that researchers consider things as they are, and do not manipulate the existing environment (Groat and Wang, 2013). In general, this research is divided into three stages, namely: (1) literature review, (2) data collection, and (3) data analysis. A literature review is carried out to synthesise various relevant theories to formulate questions and solve research problems (Groat and Wang, 2013). In this study, the 
literature review played a role in developing an assessment tool to measure or evaluate the sustainability of construction and the material life cycle of the transitional shelter.

The second stage is data collection. In qualitative research methods, the perspective of the researcher has the potential to lead to interpretations that may be biased, so it is necessary to involve various points of view that distinguish the many factors involved in a situation to increase objectivity (Groat and Wang, 2013). This study used two different primary data collection methods, namely observation and interviews. The use of two different data collection methods is believed to be complementary to each other, resulting in a better and more comprehensive understanding (Groat and Wang, 2013). Observations were conducted to understand the physical condition of the building, including the construction system used and the use of materials in the transitional shelter.

In contrast, interviews were conducted to understand the use of the transitional shelter from the perspective of disaster victims as construction users. Interviews included several parties, namely: (1) several victims of the eruption of Mount Merapi who had occupied post-disaster shelters / transitional shelters, and (2) representatives from the National Disaster Management Agency (BNPB) as the party which provided assistance. Interviews were conducted in-depth and involved open-ended questions so that researchers could understand the real conditions that occurred in the transitional shelter as a post-disaster temporary shelter. The use of open-ended questions also allows an unlimited variety of answers to be obtained to provide infinite insights, as well as allowing the author to understand the respondent's point of view.

In the final stage, the results obtained from observations regarding the construction of traditional shelter buildings were analysed against a literature review regarding the principles of DfD formulated in the literature review (table 2). The results of the analysis are then linked to the theory from DFID (2012) regarding the characteristics of a sustainable transitional shelter, to determine whether the transitional shelter design used in the post-eruption disaster of Mount Merapi meets the intended sustainable criteria. Lastly, the interview verified the real situation that occurs after the use of the transitional shelter: whether or not it is being used sustainably.

\section{RESULTS AND DISCUSSION}

\section{Transitional Shelter for the 2010 Mount Merapi Eruption Disaster}

Mount Merapi is one of the most active volcanoes in Indonesia. The eruption in 2010 was the most massive Mount Merapi eruption ever recorded in history as well as defeated the power of the same mountain eruption in 1872 (Head of BPPTKG Yogyakarta, 2010 in Joewono, 2010). The first eruption of the series occurred on 26 October 2010 and peaked on 5 November 2010, marked by a more violent eruption which led to the determination that the safe distance was $20 \mathrm{~km}$ radius from the top of the mountain (Linawati, 2019). 


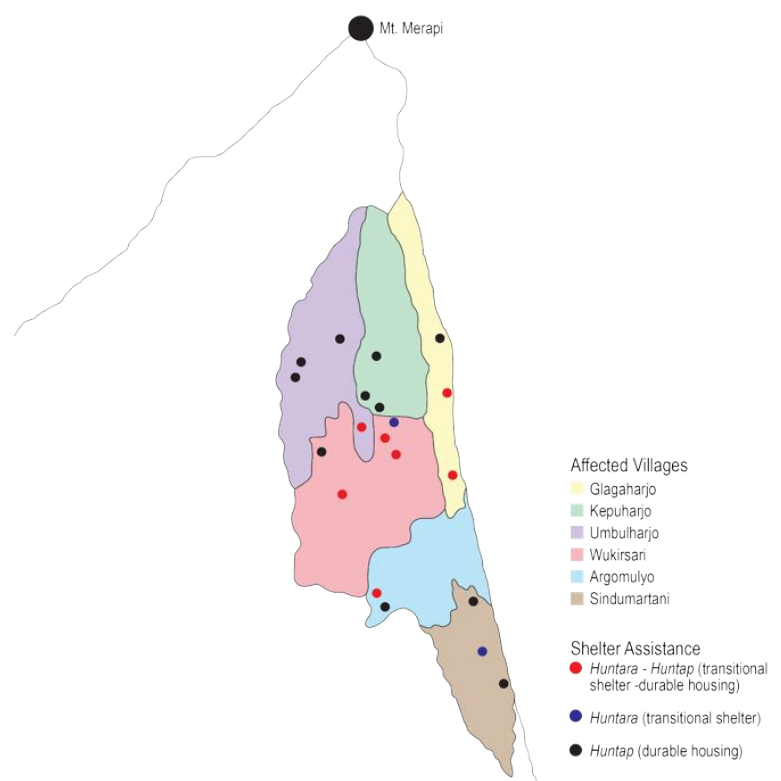

Figure 3. Map of distribution of housing assistance locations for victims of the 2010 Mount Merapi eruption source: BNPB, 2016 (reproduced)

The data from BNPB (2011) shows that there were at least six villages in two sub-districts around Mount Merapi that had suffered severe damage due to the eruption. The six villages are Umbulharjo Village, Glagaharjo Village, Kepuharjo Village, Wukirsari Village, Argomulyo Village in Cangkringan District, and Sindumartani Village in Ngemplak District (figure 3). The affected communities from the six villages were to receive assistance in the form of rehabilitation for house repairs or in the form of durable housing. However, because the aid could not be quickly available, a huntara was needed as a transitional shelter.

Data from 2016 shows that the number of transitional shelters built was 2,682 units, while the number of post-disaster durable housings was 1,706 units: showing a 976 difference in the number of transitional shelters and durable housing. This difference is because not all people affected by the eruption choose to return to live around Mount Merapi, or because the original houses of the affected communities can still be rehabilitated. The transitional shelter built after the eruption of Mount Merapi in 2010 became the object of research discussed in this study.

The transitional shelter consists of a family room with dimensions of $3 \mathrm{~m} \times 4 \mathrm{~m}$, two bedrooms, each with dimensions of $3 \mathrm{~m} \times 2 \mathrm{~m}$, one bathroom with dimensions of $1.5 \mathrm{~m} \times 2 \mathrm{~m}$, and a kitchen with dimensions of $3 \mathrm{~m} \times 2 \mathrm{~m}$, adding up to a total of approximately $36 \mathrm{~m} 2$ (figure 4). These guidelines were determined by the Governor of DIY (2010), as stipulated in the DIY Governor Regulation number 40.2 of 2010 concerning Guidelines for the Implementation of Temporary Residential Area Development. Considering that the design refers to the regulations, all of the constructed transitional shelters followed these established guidelines instead of responding to the specific needs of each victim's family. 

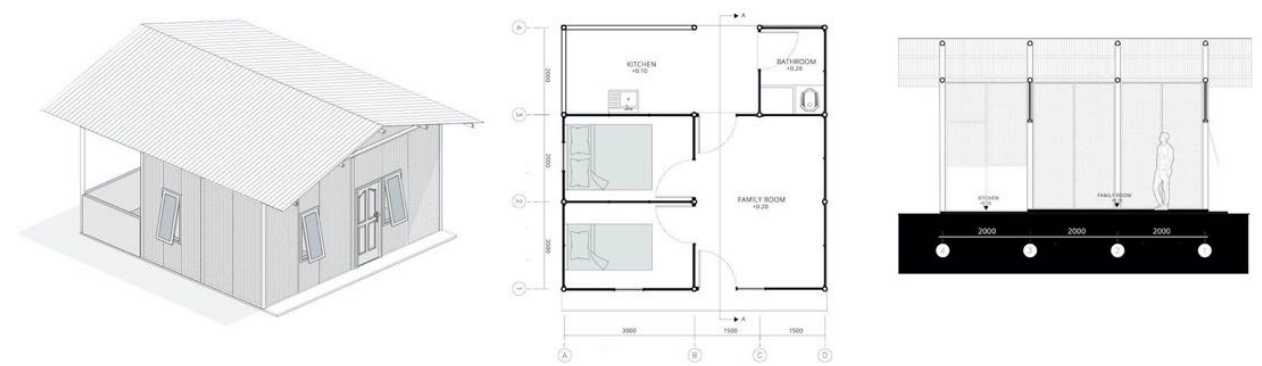

Figure 4. Transitional shelter design for victims of the 2010 Mount Merapi eruption source: Arisya, 2020

The materials used in the construction of the transitional shelter for the 2010 eruption of Mount Merapi included bamboo, zinc, concrete blocks, and concrete. In this transitional shelter, concrete was used for the base for the transitional shelter, zinc for roof coverings, bricks for particular areas such as the kitchen and bathroom areas, and bamboo for superstructures and walls (figure 5). The bamboo used as a structure did not get special treatment: long bamboo only undergoes cutting and shaping according to size and needs. As for the walls, woven bamboo became the primary material. The bamboos for the roof of this transitional shelter are connected using the lashing technique - a tie or knot using a rope used to connect one bamboo pole to another according to particular needs (Janssen, 2000; GSOCCC, 2016).

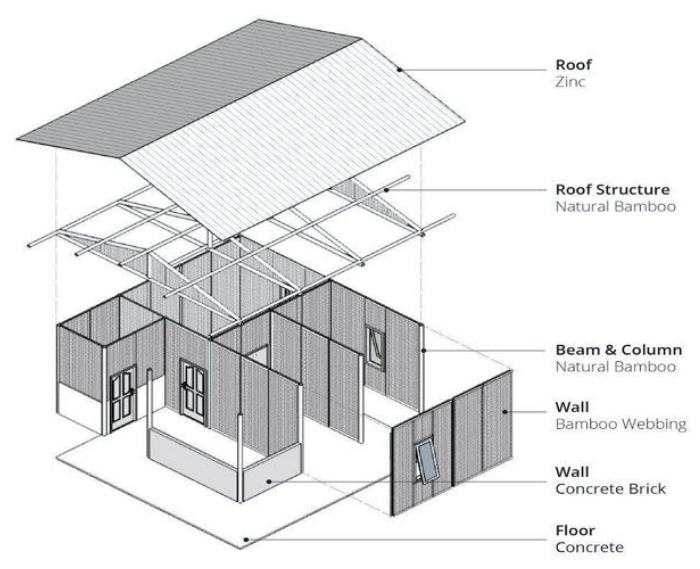

Figure 5. The use of materials in the transitional shelter for victims of the 2010 Mount Merapi eruption source: Arisya, 2020

\section{Data Analysis}

Based on the elaboration in the previous chapter, the DfD principle in transitional shelter construction was used as a benchmark for measuring the potential for material 
loops. In $\mathrm{DfD}$, several main principles are part of measuring this potential, namely: (1) the choice and treatment of materials, (2) easy-to-separate joints, (3) layer separation, and (4) component modularity. In the transitional shelter for the eruption of Mount Merapi, the application of these principles includes:

a. Materials

In this study, two aspects were considered in the selection and use of materials, namely: (1) originality of the material (relates to treatment); and (2) weight of the material (heavy or light). In terms of treatment, it was found that some parts of the transitional shelter for the eruption of Mount Merapi use pure materials, such as bamboo and zinc. These two materials were not given any treatment that changes the original character of the material, such as painting or coating. With the use of untreated materials, building components have more potential to be recycled back into new components because there is no material contamination (Cairns and Jacobs, 2014).

In terms of weight, bamboo and zinc materials were not too heavy and considered to be in the lightweight material category. The use of lightweight materials can facilitate material transportation so that it automatically supports the relocation of components for use in different locations (Crowther, 1998).

This finding suggests that bamboo and zinc have similar impacts-in terms of characteristic originality (treatment for building use) and material weight. However, it should be borne in mind that there are various other factors that distinguish the environmental impacts caused by the two materials.

b. Layer Separation

Referring to the layer mapping defined by Brand (1994), the transitional shelter for the eruption of Mount Merapi only consists of the site layer, structure, skin-space which appears to be the same, and "stuff" (furniture). The site to structure layer (foundation) in this building is considered inseparable. The casting technique used on the foundation makes it difficult to see the relationship between the foundation and the site, making it more nearly impossible to separate the layers for relocation purposes. Meanwhile, the structural layer in the form of a column with plan-forming elements (walls and roof) is considered as separate because the relationship between the materials is still visible. With the separation of the structural layers (columns and beams) from the walls, the parts can be separated without disturbing one another. This separation, of course, supports the ease maintenance of the building components if damaged, and even increases the building's ability to be changed in function if ever needed.

c. Joints and Connections

The selection and use of joints and connections on the DfD principle consider several things, including (1) joints that are easily separated; and (2) easily accessible connections. In terms of separability, in this transitional shelter, several parts were found that used the type of joint which can be separated without damaging the material. This joint is located at the connection of bamboo structures (column to beam, beam to beam), as well as in the connection of bamboo (roof structure) with the zinc (roof cover). Each bamboo stick is 
connected to one another using lashing techniques, which is a method used to join together poles or 'spars' with rope (GSOCCC, 2016). The use of lashing technique (figure 6) in the form of knots as a connection between bamboos in this building allows it to be dismantled again without damaging the material itself(Janssen, 2000; GSOCCC, 2016). Thus, the physical quality of the material can be maintained if reused (Cairns and Jacobs, 2014).

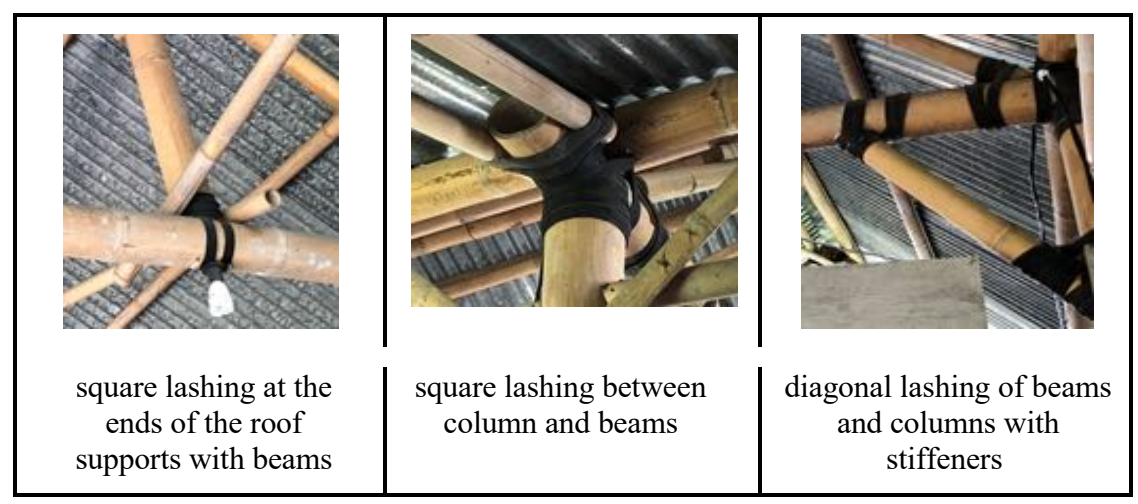

Figure 6. The use of the lashing technique as a connection between bamboos at the transitional shelter for victims of the 2010 Mount Merapi eruption source: Pratiwi, 2018

As opposed to the joints between bamboos, which were proven to be separable, the joints found in other building components still used nails or chemical joints (e.g., cast concrete floor, brick walls, etc.) which were considered inseparable. These types of joints will further affect the demolition process, which should be carried out in a structured manner as the main idea of DfD (Jensen and Sommer, 2016). Although structured dismantling is still possible with joints that use nails (the reverse of the installation sequence), these joints do not entirely guarantee the possibility of maintaining the physical quality of the material for reuse.

When the connection has met the requirements of separability, it also needs to be ensured that the joint is easily accessible. In the connection between the bamboo structure and the roof, apart from being easily separable, the position of the joints was left exposed which allows for easier access for its maintenance.

d. Standardized Components (Modularity)

In the transitional shelter for the eruption of Mount Merapi, several constituent components used are modular-having the same type of material, treatment and size (figure 7). Some of the modular components, among others, are the constituents of the roof trusses, columns, and also several of the woven bamboo walls. More so, the room layout with the standard spacing of $3 \times 3$ between columns is one of the things that influence the formation of modular infill walls. 


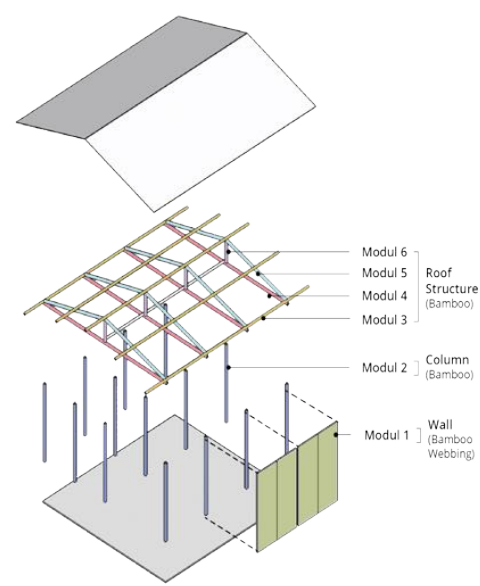

Figure 7. Modular component in the design of transitional shelter for victims of the 2010 Mount Merapi eruption source: Arisya, 2020

The use of this modular component, as stated earlier, can speed up the construction process which automatically will facilitate the dismantling and assembly process when the building is about to be relocated (Crowther, 1998; Ikaputra, 2008). In addition, the modularity allows the components of the fellow modules to be exchanged with each other. This modularity, of course, supports the reuse of components in buildings in the same location or different locations.

From the previous analyses, a synthesis can be carried out to determine whether the building components at the transitional shelter for the victims of the 2010 Merapi eruption had met the DfD principle. As stated in table 3, it was found that most of the building components in the transitional shelter for victims of the eruption of Mount Merapi meet the principles of DfD. In other words, this supports the potential for material loops to occur in these components so that they can fulfil the characteristics of a sustainable transitional shelter stated by DFID (2012).

Table 3. Analysis of observation results from the transitional shelter the $2010 \mathrm{Mt}$. Merapi eruption, based on the principles of DfD

\begin{tabular}{|c|c|c|c|c|c|c|c|}
\hline \multirow{3}{*}{$\begin{array}{l}\text { Building } \\
\text { Components }\end{array}$} & \multicolumn{6}{|c|}{ Design for Disassembly Principles } & \multirow{3}{*}{$\begin{array}{c}\text { Sustainable } \\
\text { Characteris- } \\
\text { tics }\end{array}$} \\
\hline & \multicolumn{2}{|c|}{ Material } & \multirow{2}{*}{$\begin{array}{l}\text { Separated } \\
\text { Layer }\end{array}$} & \multicolumn{2}{|c|}{ Joint } & \multirow{2}{*}{$\begin{array}{l}\text { Standard } \\
\text { Com- } \\
\text { ponent }\end{array}$} & \\
\hline & $\begin{array}{l}\text { Natu- } \\
\text { ral }\end{array}$ & $\begin{array}{l}\text { Light- } \\
\text { weight }\end{array}$ & & $\begin{array}{l}\text { Separ- } \\
\text { able }\end{array}$ & $\begin{array}{c}\text { Access- } \\
\text { ible }\end{array}$ & & \\
\hline Substructure & $\mathrm{x}$ & $\mathrm{x}$ & $\mathrm{x}$ & $\mathrm{x}$ & $\mathrm{x}$ & $\mathrm{x}$ & - \\
\hline Floor & $\mathrm{x}$ & $\mathrm{x}$ & $\mathrm{x}$ & $\mathrm{x}$ & $\mathrm{x}$ & $\mathrm{x}$ & - \\
\hline
\end{tabular}


Table 3. Analysis of observation results from the transitional shelter the 2010 Mt. Merapi eruption, based on the principles of DfD (continued)

\begin{tabular}{|c|c|c|c|c|c|c|c|}
\hline \multirow{3}{*}{$\begin{array}{l}\text { Building } \\
\text { Components }\end{array}$} & \multicolumn{6}{|c|}{ Design for Disassembly Principles } & \multirow{3}{*}{$\begin{array}{c}\text { Sustainable } \\
\text { Characteris- } \\
\text { tics }\end{array}$} \\
\hline & \multicolumn{2}{|c|}{ Material } & \multirow{2}{*}{$\begin{array}{l}\text { Separated } \\
\text { Layer }\end{array}$} & \multicolumn{2}{|c|}{ Joint } & \multirow{2}{*}{$\begin{array}{l}\text { Standard } \\
\text { Com- } \\
\text { ponent }\end{array}$} & \\
\hline & $\begin{array}{c}\text { Natu- } \\
\text { ral }\end{array}$ & $\begin{array}{l}\text { Light- } \\
\text { weight }\end{array}$ & & $\begin{array}{l}\text { Separ- } \\
\text { able }\end{array}$ & $\begin{array}{l}\text { Access- } \\
\text { ible }\end{array}$ & & \\
\hline Superstructure & $\mathrm{v}$ & $\mathrm{v}$ & $\mathrm{v}$ & $\mathrm{v}$ & $\mathrm{v}$ & $\mathrm{v}$ & $(1)(2)(3)(4)(5)$ \\
\hline Wall & $\mathrm{v}$ & $\mathrm{v}$ & $\mathrm{v}$ & $\mathrm{v}$ & $\mathrm{v}$ & $\mathrm{v}$ & $(1)(2)(3)(4)(5)$ \\
\hline Roof Structure & $\mathrm{v}$ & $\mathrm{v}$ & $\mathrm{v}$ & $\mathrm{v}$ & $\mathrm{v}$ & $\mathrm{v}$ & $(1)(2)(3)(4)(5)$ \\
\hline Roof & $\mathrm{v}$ & $\mathrm{v}$ & $\mathrm{v}$ & $\mathrm{v} / \mathrm{x}^{* *}$ & $\mathrm{v}$ & $\mathrm{v}$ & $(1)(2)(3)(4)(5)$ \\
\hline
\end{tabular}

Notes: (1) Upgradable; (2) Reusable; (3) Recyclable; (4) Relocatable; (5) Resalable

$* \mathbf{v}$ means the principles are applicable to the building component, $\mathbf{x}$ means the principles are not applicable.

**v / $\mathbf{x}$ means the principle is only applicable to some extent: in this case, the roof joints possible to be separated, yet leaving behind several irreversible marks to the material

According to the results of the interview, the transitional shelter construction process is not only intended to meet individual or family needs, but also includes meeting communal needs such as community halls and libraries. The interview showed that after the affected community moved to a new location where the durable housing was, the community hall was converted into a public kitchen for the nearby campsite (figure 8). This shows that there are initiatives and efforts to utilise post-use buildings to reduce waste, which is in line with the reusable principle stated in regards to a sustainable transitional shelter construction (DFID, 2012).

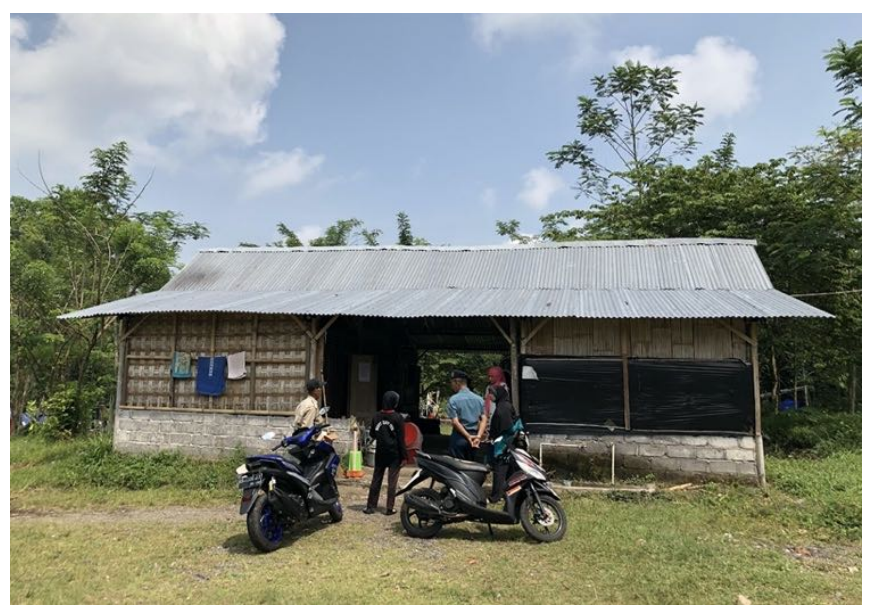

Figure 8. Former community hall for the victims, turned into a public kitchen for the nearby campsite after the victims have relocated

source: Pratiwi, 2018 
In another case, there were other forms of attempts done by some residents to make use of the building - or more precisely building components - by people who are trying to rebuild the transitional shelter in another place. This case was found in Jetis Sumur Village, where the community attempted to move the temporary transitional shelter to a site close to a durable housing location so that they could return to their place of origin when construction had completed. This information is consistent with the results of the previous analysis, which showed that most of the transitional shelter building components were relocatable. Unfortunately, this research cannot prove it directly through observation, considering that now there are no transitional shelters left in the site.

The data collected also show that there are efforts made by specific individuals to reuse the components of their former transitional shelter buildings. The results of an interview with one of the victims of the disaster (2018) showed that he had successfully reused the transitional shelter building component in the form of zinc (roof) to be used again as a roof cover on his durable housing extension.

The results of the interviews and observations above indicate that the potential of the existing loops material had not been fully utilised. The observational analysis was successful in showing that for the most part, the transitional shelter buildings could meet the DfD principles and the building components had the potential for material loops to occur. Unfortunately, both the affected community as well as the aid providers were not fully aware of this potential: thus, the material loop could not be optimal. This lack of awareness also causes the perception that the transitional shelter is only a temporary stop so that its potential for the long term was not realised. This assumption does not only apply to the community as recipients but also to aid providers who sometimes feel that the construction of transitional shelters for disaster victims is considered inappropriate - even a waste of budget-because of its temporary nature (tempo.co, 2010). Even if the planning had been done properly and takes into account the entire life cycle-from the construction process to post-usethe construction of transitional shelter could potentially be used in the longer term: therefore, minimising waste and possibly increasing efficiency as well as lowering building cost (Jha, 2010; IFRC, 2011; DFID, 2012).

\section{CONCLUSIONS}

The provision of transitional shelter is an essential step in disaster management as a form of support for affected communities before they can rebuild more permanent houses. Given its temporary nature, transitional shelters have an extensive enough potential to produce waste that can damage the environment, so the design considerations need to be carried out carefully - from the construction process, up to the post-use. In order to reduce the negative impact on the environment, transitional shelters need to be designed with a longer life cycle, taking into account the potential for material loops to occur: thus, the various principles of Design for Disassembly should be considered to achieve the desired sustainability. This research proves that the construction of shelters for victims of the 2010 Merapi eruption disaster can be said to have almost wholly fulfilled the DfD principles - both in terms of materials, 
layers, joints, and component modularity-thus, supporting the potential for material loops. However, in practice, there are only a few cases of transitional residential houses that are wholly or partly reused (components only), the rest are immediately dismantled and disposed of after the useful life of the transitional shelter ends. This shows that the potential for material loops in transitional shelters has not been fully realised - both by the aid providers and by impacted victims as building users. These facts are considered quite unfortunate, especially considering that Indonesia is a country that is very prone to disasters so that huntara as transitional shelters will often be needed.

For this reason, the authors believe that further studies are required to formulate various design standards for Transitional Shelter in Indonesia to optimise the potential for longevity and minimise environmental impacts. These standards can be used as guidelines-for both transitional shelter assistance providers and recipients - to optimise the potential of existing materials so that buildings can be sustainable and minimise negative impacts on the environment. The functional standard for postdisaster transitional shelter-in terms of size, function, and spatial program - should be regulated at the national level to ensure fulfilment of basic needs. Furthermore, the provincial level can adapt these standards to suit the local context, for example in terms of material use and environmental climatic conditions. In developing these standards, input from the community, such as practitioners, researchers, or experts, could highly contribute in providing broader knowledge related to sustainable construction. Therefore, the standards would not only consider the functional aspects when the building is being used, but also keeping in mind about sustainability, especially those related to the buildings' post-use stage.

\section{REFERENCES}

BNPB (2008) 'Peraturan Kepala Badan Nasional Penanggulangan Bencana no. 7 Tahun 2008 Tentang Pedoman Tata Cara Pemberian Bantuan Pemenuhan Kebutuhan Dasar'. Badan Nasional Penanggulangan Bencana, p. 34.

BNPB (2017) Potensi Ancaman, Badan Nasional Penanggulangan Bencana. Available at: https://www.bnpb.go.id/potensi-ancaman-bencana (Accessed: 22 July 2020).

BNPB (2020) Tren Kejadian Bencana 10 tahun terakhir, Data Informasi Bencana Indonesia. Available at: https://bnpb.cloud/dibi/ (Accessed: 22 July 2020).

Brand, S. (1994) How Buildings Learn: What happens after they're built. London: Penguin Books Ltd.

Cairns, S. and Jacobs, J. M. (2014) Buildings Must Die: A Perverse View of Architecture. Cambridge: MIT Press Ltd.

Crowther, P. (1998) 'Design for Disassembly: An Architectural Strategy', in Proceedings of the 1998 QUT Winter Colloquium, pp. 27-33.

Crowther, P. (1999) 'DESIGN FOR DISASSEMBLY TO RECOVER EMBODIED ENERGY', in The 16th International Conference of Passive and Low Energy Architecture. Brisbane.

Crowther, P. (2001) 'Developing an Inclusive Model for Design for Deconstruction', 
CIB Publication 266, CIB Task G(Decosntruction and Materials Reuse; Technology, Economic and Policy). Available at: https://www.irbnet.de/daten/iconda/CIB744.pdf.

DFID (2012) 'Transitional Shelter Guidelines'. Geneva: Department for International Development; International Organization for Migration. Available at: https://issuu.com/joashbridge/docs/transitional_shelter_guidelines.

Groat, L. N. and Wang, D. (2013) Architectural Research Methods. 2nd Ed. New York: John Wiley \& Sons, Inc.

GSOCCC (2016) 'Lashing Manual', Girl Scouts of California's Central Coast.

Guy, B. and Shell, S. (2002) 'Design for Deconstruction and Materials Reuse', Proceedings of the CIB Task Group 39 - Deconstruction Meeting, 272(April). Available at: https://citeseerx.ist.psu.edu/viewdoc/download?doi=10.1.1.624.9494\&rep=rep $1 \&$ type $=$ pdf.

IFRC (2010) 'The IFRC shelter kit'. International Federation of Red Cross and Red Crescent Societies, p. 88.

IFRC (2011) Transitional Shelters Eight Designs. Geneva: International Federation of Red Cross and Red Crescent Societies.

IFRC and UN-OCHA (2015) Shelter After Disaster 2nd Edition. 2nd Editio. Edited by I. Davis, P. Thompson, and F. Krimgold. International Federation of Red Cross and Red Crescent Societies; United Nations Office for the Coordination of Humanitarian Affairs.

Ikaputra (2008) 'CORE HOUSE: A STRUCTURAL EXPANDABILITY FOR LIVING Study Case of Yogyakarta Post Earthquake 2006', Dimensi : Journal of Architecture and Built Environment, 36(1), p. pp.10-19. doi: 10.9744/dimensi.36.1.pp.

Janssen, J. J. A. (2000) Designing and Building with Bamboo. vol. 20. Beijing: International Network for Bamboo and Rattan (INBAR).

Jensen, K. G. and Sommer, J. (2016) Building a Circular Future. 3rd edn. GXN Innovation.

Jha, A. K. (2010) Safer Homes, Stronger Communities: A Handbook for Reconstructing after Natural Disasters, Safer Homes, Stronger Communities. Washington DC: The International Bank for Reconstruction and Development / The World Bank. doi: 10.1596/978-0-8213-8045-1.

Joewono, B. N. (2010) Erupsi Merapi 2010 Lebih Besar dari 1872, Kompas.com. Available

at: https://megapolitan.kompas.com/read/2010/11/09/15573541/erupsi.merapi.20 10.lebih.besar.dari.1872?page=all (Accessed: 20 August 2020).

Kibert, C. J. (2016) Sustainable Construction: Green Building Design and Delivery. 4th Editio. Hoboken: John Wiley \& Sons, Inc.

Kronenburg, R. (2014) 'Shelter after Disaster', in Architecture in Motion: The History and Development of Portable Building. New York: Routledge Taylor \& Francis Group, pp. 169-187.

Latief (2011) Huntara Tak Jelas , Korban Merapi Demo, Kompas.com. Available at: https://tekno.kompas.com/read/2011/02/28/11311517/Huntara.Tak.Jelas.Korb an.Merapi.Demo. 
Linawati, M. (2019) Dahsyatnya Letusan Gunung Merapi 5 November 2010, liputan6.com. Available at: https://www.liputan6.com/news/read/4102868/dahsyatnya-letusan-gunungmerapi-5-november-2010 (Accessed: 20 August 2020).

Pramishinta, P. A. and Widyarko (2021) 'Flexible housing implementation in domeshape post-disaster relief house: Is it possible?', IOP Conference Series: Earth and Environmental Science, 716(1). doi: 10.1088/1755-1315/716/1/012136.

Putra, Y. M. P. (2020) Hanya 248 Keluarga Korban Bencana di Bogor, Republika. Available at: https://republika.co.id/berita/q5yj1b284/hanya-248-keluargakorban-bencana-di-bogor-ajukan-huntara (Accessed: 22 July 2020).

Setiyoko, E. and Mardiani, D. (2013) Ratusan Huntara Pengungsi Merapi Dibongkar, Republika. Available at: https://www.republika.co.id/berita/nasional/jawatengah-diy-nasional/13/02/05/mhqp08-ratusan-huntara-pengungsi-merapidibongkar.

tempo.co (2010) Pemprov Jateng Bangun 366 Rumah Sementara Korban Merapi, tempo.co. Available at: https://nasional.tempo.co/read/294060/pemprovjateng-bangun-366-rumah-sementara-korban-merapi/full\&view $=$ ok (Accessed: 22 July 2020).

UNDRO (1982) 'Shelter after Disaster: Guidelines for Assistance'. Geneva: Office of United Nations Disaster Relief Co-ordinator.

Zhao, L. et al. (2017) 'Planning emergency shelters for urban disaster resilience: An integrated location-allocation modeling approach', Sustainability (Switzerland), 9(11), pp. 1-20. doi: 10.3390/su9112098. 